\title{
The Effect of Microcredit on the Relationship Between Sustainability Practices and Business Performance of Microenterprises in Malaysia
}

Noorul Hafizah Hashim, Hisham Mohammad

To Link this Article: http://dx.doi.org/10.6007/IJARBSS/v11-i6/10110

DOI:10.6007/IJARBSS/v11-i6/10110

Received: 08 April 2021, Revised: 10 May 2021, Accepted: 29 May 2021

Published Online: 09 June 2021

In-Text Citation: (Hashim et al., 2021)

To Cite this Article: Hashim, N. H., \& Mohammad, H. (2021). The Effect of Microcredit on the Relationship Between Sustainability Practices and Business Performance of Microenterprises in Malaysia. International Journal of Academic Research in Business and Social Sciences, 11(6), 196-202.

Copyright: (c) 2021 The Author(s)

Published by Human Resource Management Academic Research Society (www.hrmars.com) This article is published under the Creative Commons Attribution (CC BY 4.0) license. Anyone may reproduce, distribute, translate and create derivative works of this article (for both commercial and non-commercial purposes), subject to full attribution to the original publication and authors. The full terms of this license may be seen at: http://creativecommons.org/licences/by/4.0/legalcode

Vol. 11, No. 6, 2021, Pg. 196 - 202

Full Terms \& Conditions of access and use can be found at http://hrmars.com/index.php/pages/detail/publication-ethics 


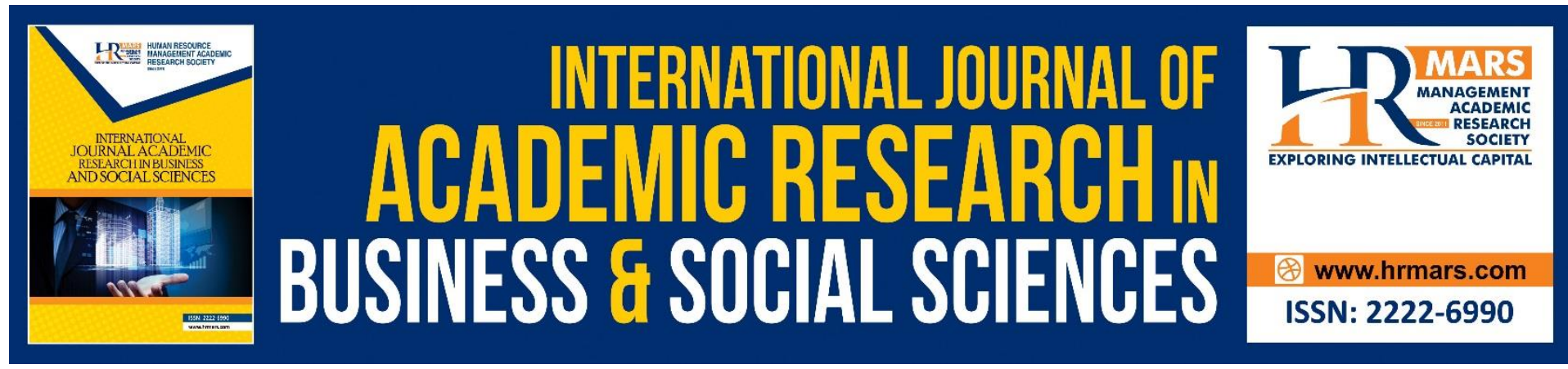

\title{
The Effect of Microcredit on the Relationship Between Sustainability Practices and Business Performance of Microenterprises in Malaysia
}

\author{
Noorul Hafizah Hashim ${ }^{1}$, Hisham Mohammad² \\ ${ }^{1}$ Faculty of Business and Management, Universiti Sultan Zainal Abidin, Kuala Terengganu, \\ Terengganu, ${ }^{2}$ School of Economics, Finance \& Banking, Universiti Utara Malaysia Malaysia, \\ Sintok, Kedah
}

\begin{abstract}
The aim of this paper to investigate the impact of microcredit on the relationship between sustainability practices and business performance of microenterprises in Malaysia. Previous studies indicated the important sustainability practices on business performance however, most of the study are looking at larger organiszation and less to microenterprises. Furthermore, there are also certain research found negative relationship of sustainability practices on business performance. The results are inconsistent. Thus, this study try to bridges these gap by focussing on microenterprise and introduce microcredit as a moderator. This study will use PLS-SEM software as an analytical tools in order to analyse the data. This study will benefited to the microenterprises in order for them enhance their business performance. Thus, the aspiration of Malaysian Government to become higher income country in 2025 could be achieve.
\end{abstract}

Keywords: Sustainability, Microcredit, Business Performance, Microenterprise

\section{Introduction}

Microenterprises play a vital role in employment and income-generating activities, improving the living standard, and indirectly, eliminating poverty (Thaker \& Mohammed, 2015). According to SME Corporation Malaysia, microenterprises are referring to an organisation or business whose recorded an annual sales turn-over less than RM300,000 and employed less than five full-time workers (SME Corporation Malaysia, 2013). In Malaysia, microenterprises are placed under Small and Medium Enterprises (SMEs) sector. SMEs become the most significant contributor to the country, with the contribution of 37 percent to Malaysian GDP and 66 percent of the employment (SME Corporation Malaysia, 2018). The number of SME establishments recorded significant growth each year as reported by SME Corporation Malaysia; in 2015 , approximately 98.5 percent of the business was established as a SME out of the total establishment in that year (SME Corporation Malaysia, 2016). Although it shows an increase in business establishment, however, the business failure is also high, at about 60 percent (Nordin, Hamid, \& Chong, 2011; Chong, 2012; Rahman, Yaacob, \& Radzi, 2016).

The performance of business could be influence by sustainability practices. Past literature has given the evidence that sustainability practices and business performance are correlated; 
however, most of enterprises are facing financial constrain in order to practicing sustainability (Johari \& Komathy, 2019; Midgett et al., 2019; Seles et al., 2019; Sy, 2016)

Recognising the critical role plays by microenterprises in developing Malaysian economic, and the Malaysian government vision to increase the contribution of SMEs to national GDP to 45 percent and 50 percent in the year 2025 and 2030 respectively, it is crucial for microenterprises owner to enhance their business performance. Most studies of business performance are more focussing on SMEs and little on microenterprises. To date there have been not many empirical studies that examined the performance of microenterprises as an outcome. In addition, there is no study has been carried out to examine the effect of microcredit on the relationship between sustainability practices and business performance of microenterprises. Therefore, there is a need to examine these relationship further. The focus of this article is to propose a framework that examine the moderating effect of microcredit on the relationshipship between sustainability practices and business performance of microenterprises in Malaysia.

Specifically, the objectives of this study is:

1. to investigate the influence of sustainability practices on business performance of microenterprises.

2. to examine the moderating effect of microcredit on the relationship between sustainability practices and business performance of microenterprises.

\section{Literature Review \\ Business Performance}

The performance of microenterprises could be defined as their capability to lead to the creation of employment and wealth by business start-up, survival, and sustainability (Sandberg, Vinberg \& Pan, 2002; Moorthy et al., 2012). Khan, Zafar, Obaidullah, and Alam (2011), define firms' performance as the success of the firm in the market even though it may generate a different outcome. Some researchers viewed performance as business performance, firm performance, organisational performance or company performance.

Many empirical study has been conducted to see the factors that could influence business performance of an organisation either for small or large organisations such as study done by Moorthy et al (2012); Jasra, Khan, Hunjra, Rehman, \& Azam (2011), Alom, Abdullah, Moten, and Azam (2016), and Nasip, Hassan, and Muda (2013) however, study on the effect of sustainability practices towards business performance are limited.

\section{Sustainability Practices}

Sustainability is the development to meet the current needs without compromising the future generation needs (Johari \& Komathy, 2019). It also could be divided into three categories which are environment, social and economics. In this study, sustainability has been define as environment management practices. Study conducted by Johari and Komathy (2019) to explore the relationship between sustainability and firm' performance in Malaysia. They found sustainability has a positive relationship with firms' performance. Meanwhile, U. Sy (2016) conducted a study at five multinational firms in Cebu that found that sustainability practices significantly affect business performance. Futhermore, Ameer and Othman (2012), claimed in their study that the company who emphasis more on sustainability practices could gain higher financial performance.

Meanwhile, Vijayan, Kamarulzaman, and Abdullah (2014) conducted a study on the sustainability practices among grocery retail industry in Malaysia. In their study, sustainability 
has been operationalized as green supply chain management. They examine the current situation and also the barriers of implementing sustainability practices by multi-format grocery retail industry in Malaysia. This study found that the level of sustainability implementation based on the type of retail format. For a small retailer, they are more focused on demands from the customer for planning operations and practice take-back; they are not following reverse logistics practices, promotion of the green product, and consumer education.

In the meantime, Seles, Jabbour, Jabbour, Latan, and Roubaud (2019) conducted a study to examine the effect of environmental practices on the business performance and environmental performance on several firms in Brazil during the economic crisis from 2013 to 2017. The findings from the study revealed that environment practices which are linked to several strategies by the company still could increase the performance of the business during the economic crisis.

On the other hand, Omri, Courrent, and Chasse (2016) conducted a study on SMEs in France, to test the sustainability practices as a moderator on the relationship between entrepreneurial orientation on the firms' performance. In their study, sustainability practices has been measured in three categories, which are environmental practices, social practices in the workplace, and social practices in the community. The finding from this study reveals that environmental practices are negatively insignificant towards firms' performance.

Thus, the following hyphothesis is developed

$H_{1}$ : Sustainability practices positively influence business performance of microenterprise.

\section{Microcredit}

Microcredit is one of the financing resources that could assist micro-enterprises to get funding, and it is essential to enhance the business performance (Mahmood \& Rosli, 2013; Mahmood et al., 2015). Many previous research has confirmed the positive effect of microcredit as a financial assistant to the needed group especially microenterprises, such as reseach conducted by Basheer (2019); Mahmood and Rosli (2013); Mustapa, Mamun, Anuar, and Hayat (2019). Most of entrepreneur facing difficulties to perform well because of high cost (Midgett et al., 2019; Vijayan et al., 2014) and need financial assistant (Mokhtar \& Ashhari, 2015).

Basheer (2019), conducted a study on the effect of microfinance programme in Malaysia, namely Amanah Ikhtiar Malaysia (AIM) on the microenterprises success in Sabah, Malaysia. By adopting cross-sectional research design he found that microfinance (AIM) has a positive and significant relationship towards microenterprises success. Nawai and Shariff, (2011) also argue the important of microcredit to the microenterprises. They believe that microcredit could boots the performance of microenterprises. Mahmood and Rosli (2013) also stress the importan microcredit on business performance in their research on MSEs business performance in Kelantan. The result found also consistent with Mustapa, Mamun, Anuar, and Hayat (2019).

Ruslan et al. (2020) conducted a research about the impact of microcredit on business performance in Terengganu, Malaysia. Based on the study, they found that microcredit participation could enhance SMEs sales growth but not the employees growth. Meanwhile, Hassan and Ibrahim (2015) examine the effect of microcredit on the small business in Penang found that microcredit successfully increase the microenterpreneur income and have a positve effect on their business.

Thus, the following hypothesis is developed: 
$\mathrm{H}_{2}$ : The relationship between sustainability practices and business performance of microenterprises is moderated by microcredit.

\section{Propose Framework}

Figure 1 below represent the proposed farework for this research. In details, the proposed frameworks containts of three (3) contructs which is sustainability practices is independent variable, business performance of microenterprises is dependent variable. It also positions microcredit as a moderating variable.

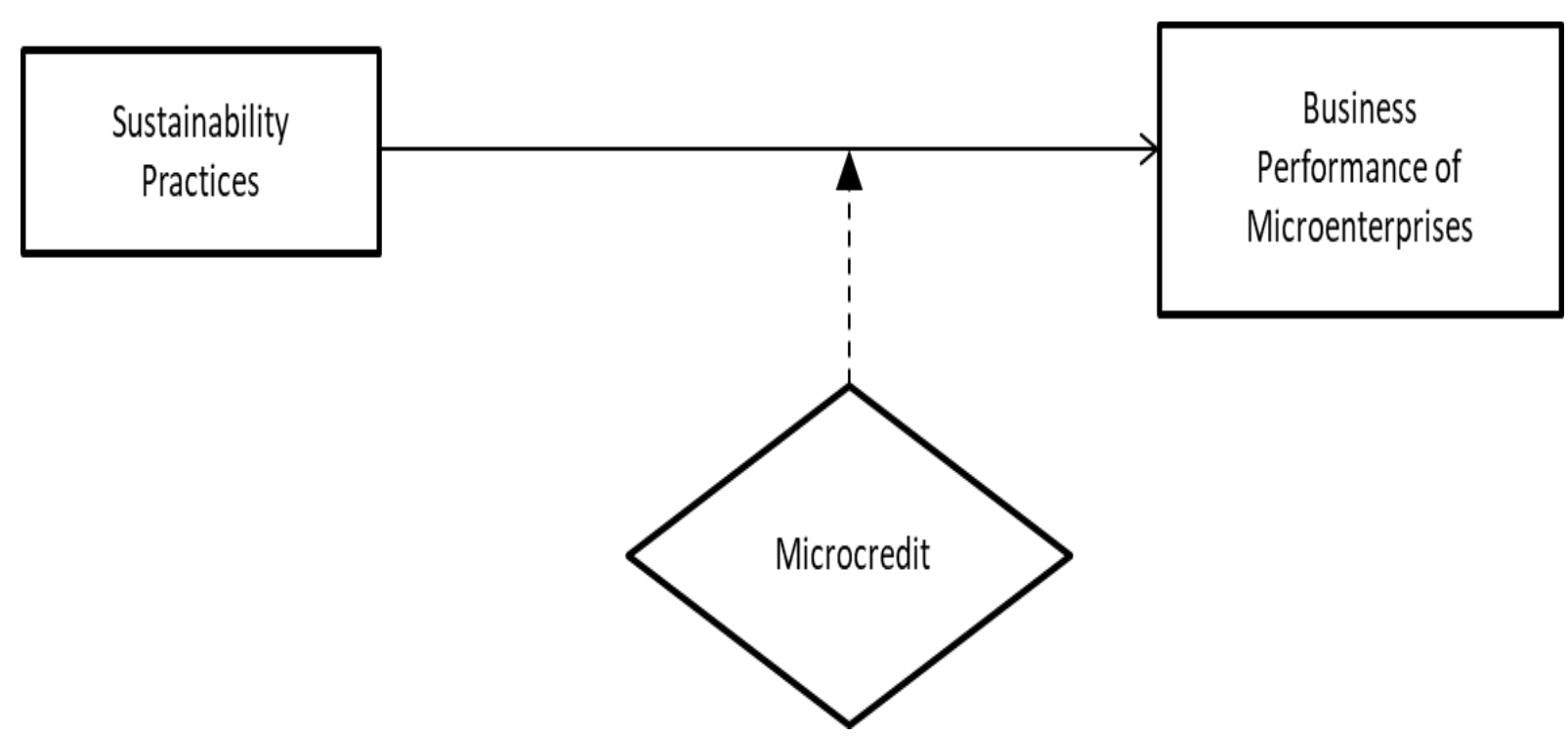

Figure 1: Proposed research framework

\section{Methodology}

The target population for this study are microenterprises from the service sector in Kedah, Malaysia. For this study, only wholesale and retail trade subsector focussing on the provision stores will be used as a sample. This study will apply the stratified random sampling technique. The statistics of the business establishment of provision stores in Kedah State requested from Companies Commission of Malaysia (SSM). The data given is based on the 12 districts in Kedah State. The data of respondents given by the Companies Commission of Malaysia (SSM) is based on the postal code. The researcher then, will categorise each respondent based on the districts to get the total number of population-based on districts. Next, the researcher will do some calculations in order to determine the sample size based on districts. Data gathered will be analysed using descriptive statistics and Partial Least Squares - Structural Equation Modelling (PLS-SEM).

\section{Conclusion}

Malaysian government's aspiration is to increase the SMEs' contribution to National GDP to 45 percent in the year 2025 and 50 percent in the year 2030 (Ministry of Entrepreneur Development (MED), 2019). Since microenterprises was the largest number of establishement in SMEs and become the largers contributor to the Malaysian gross domestic product (GDP), it is a need to examine the important factors that could increase their performance and indirectly it increase their contribution to the Malaysian gross domestic product (GDP). Thus, this paper is conducted to proposed the framework which illustare the relationship between sustainability practices and business performance of microenterpirses 
with incorporated microcredit as moderator. Also, the future findings perhaps will help the Malaysia government to

\section{References}

Alom, F., Abdullah, M. A., Moten, A. R., \& Azam, S. M. F. (2016). Success factors of overall improvement of microenterprises in Malaysia : an empirical study. Journal of Global Entrepreneurship Research, 1-13. https://doi.org/10.1186/s40497-016-0050-2

Ameer, R., \& Othman, R. (2012). Sustainability Practices and Corporate Financial Performance : A Study Based on the Top Global Corporations. Journal Business Ethics, 108(October). https://doi.org/10.1007/s10551-011-1063-y

Basheer, M. F. (2019). The Effect of Amanah Ikhtiar Malaysia ( AIM ) on Microenterprise Success in Sabah State Malaysia. The Dialogue, (July).

Chong, W. Y. (2012). Critical Success Factors for Small and Medium Enterprises: Perceptions of Entrepreneurs in Urban Malaysia. Journal of Business and Policy Research Issue. Pp.

Hassan, M. S., \& Ibrahim, K. (2015). Sustaining Small Entrepreneurs Through a Microcredit Program in Penang, Malaysia : A Case Study. Journal OfHuman Behavior in the Social Environmen, 182-191. https://doi.org/10.1080/10911359.2014.956961

Hudon, M., \& Sandberg, J. (2016). The Ethical Crisis in Microfinance: Issues, Findings, and Implications, 4(October 2013), 561-589. https://doi.org/10.5840/beq201323440

Jasra, J. M., Khan, M. A., Hunjra, A. I., Rehman, R. A. U., \& Azam, R.-I. -. (2011). Determinants Of Business Success Of Small And Medium Enterprises. International Journal of Business and Social Science, 2(20), 274-280.

Johari, J., \& Komathy. (2019). Sustainability Reporting And Firm Performance : Evidence In Malaysia. International Journal of Accounting, Finance and Business (IJAFB), 4(17), 3245.

Khan, M. A., Zafar, A., Obaidullah, M., \& Alam, M. S. (2011). Effect of Entrepreneur and Firm Characteristics on the Business Success of Small and Medium Enterprises ( SMEs) in Bangladesh. International Journal of Business and Management, 6(3), 289-299.

Mahmood, R., Zahari, M. A. S., \& Mat Zin, S. (2015). The Microcredit-Business Performance Relationship: Program Delivery Services as Mediator. Mediterranean Journal of Social Sciences, 6(6 S2), 691-701. https://doi.org/10.5901/mjss.2015.v6n6s2p691

Mahmood, R., \& Rosli, M. M. (2013). Microcredit Position In Micro And Small Enterprise Performance: The Malaysian Case. Management Research Review, 36(5), 436-453. https://doi.org/10.1108/01409171311327226

Midgett, C., Deale, C. S., Crawford, A., \& Weber, M. (2019). A Cross-Case Analysis Of Barriers To Sustainability In Small Tourism Accommodation Enterprises In Dare Country, North Carolina. Tourism and Hospitality Research, 1-13.

https://doi.org/10.1177/1467358419831425

Ministry of Entrepreneur Development (MED). (2019). Dasar Keusahawanan Nasional.

Mokhtar, S. H., \& Ashhari, Z. M. (2015). Issues and challenges of microcredit programmes in Malaysia. Asian Social Science, 11(26), 191-195.

https://doi.org/10.5539/ass.v11n26p191

Moorthy, M. K., Tan, A., Choo, C., Wei, C. S., Ping, J. T. Y., \& Leong, T. K. (2012). A Study on Factors Affecting the Performance of SMEs in Malaysia. International Journal of Academic Research in Business and Social Science, 2(4), 224-239.

Mustapa, W. N. W., Mamun, A. A., Anuar, N. I. M., \& Hayat, N. (2019). Microcredit And Microenterprises Performance In Malaysia. International Journal of Applied Behavioral 
Economics, 8(2), 1-13. https://doi.org/10.4018/IJABE.2019040101

Nasip, S., Hassan, R. A., \& Muda, N. N. (2013). Factors Affecting the Firm Performance Among Small and Medium Sized Enterprises (SMEs): A Conceptual Paper. Unpuplished, 1-16. Retrieved from http://www.ums.edu.my/fpep/files/ENT_4_2015.pdf

Nawai, N., \& Shariff, M. N. M. (2011). The importance of micro financing to the microenterprises development in malaysia's experience. Asian Social Science, 7(12), 226-238. https://doi.org/10.5539/ass.v7n12p226

Nordin, N. A. M., Hamid, A. H. A., \& Chong, C. W. (2011). Factors Affecting Profitability Of Women Entrepreneurs Business In Malaysia. In Annual Summit on Business and Entrepreneurial Studies (ASBES 2011) Proceeding.

Omri, W., Courrent, J., \& Chasse, S. (2016). Do Entrepreneurial SMEs Perform Better Because They are More Responsible ? Journal Business Ethics. https://doi.org/10.1007/s10551016-3367-4

Rahman, N. A., Yaacob, Z., \& Radzi, R. M. (2016). The Challenges Among Malaysian SME : A Theoretical Perspective. World Journal of Social Sciences, 6(3), 124-132.

Ruslan, R. A. M., Gan, C., Hu, B., \& Quang, N. T. T. (2020). Impact of Microcredit on SMEs Performance in Malaysia, 19(1), 109-130.

Seles, B. M. R. P., Jabbour, A. B. L. de S., Jabbour, C. J. C., Latan, H., \& Roubaud, D. (2019). Do Environmental Practices Improve Business Performance Even in an Economic Crisis? Extending the Win-Win Perspective. Ecological Economics, 163, 189-204. https://doi.org/10.1016/j.ecolecon.2019.04.013

SME Corporation Malaysia. (2013). SME Corporation Malaysia. Retrieved November 1, 2019, from http://www.smecorp.gov.my/index.php/en/policies/2015-12-21-09-09-49/smedefinition/87-definisi-pks-sme-info

SME Corporation Malaysia. (2016). SME Annual Report 2015/2016. Kuala Lumpur.

SME Corporation Malaysia. (2018). SME Annual Report Malaysia 2018.

Thaker, M. A. B. M. T., \& Mohammed, M. O. (2015). The Challenges Of Micro Enterprises In Malaysia And The Prospect For Integrated Cash Waqf Micro Enterprises Investment ( ICWME-I ) Model. In Small and Medium Enterprises in Selected Muslim Countries (pp. 203-222).

Vijayan, G., Kamarulzaman, N. H., \& Abdullah, A. M. (2014). Sustainability Practices In The Malaysian Grocery Retail Industry. In IAC2014 (pp. 1-4). 